\title{
正規圧密粘性土のダイレイタンシー挙動 \\ DILATANCY BEHAVIOUR OF NORMALLY CONSOLIDATED COHESIVE SOILS
}

\author{
亀井健史*・竹野毅**・常田亮*** \\ By Takeshi KAMEI, Takeshi TAKENO and Makoto TOKIDA
}

\begin{abstract}
To investigate the dilatancy characteristics of normally consolidated cohesive soils, isotropically consolidated triaxial compression test with mean effective principal stress equal to constant $(\overline{\mathrm{CIPC}} \mathrm{C})$ was performed on two soils. As a consequence, the time dependency on volumetric and shear strain rates was shown. In conventional laboratory triaxial testing, on the other hand, isotropically consolidated triaxial compression tests ( $\overline{\mathrm{CIU}} \mathrm{C})$ primarily are conducted because of convenience and simplicity of testing procedures. Comparison of $\overline{\mathrm{CIU}} \mathrm{C}$ and $\overline{\mathrm{CIPC}} \mathrm{C}$ test results suggest that the dilatancy characteristics from the $\overline{\text { CIPCC }}$ could be extrapolated from results obtained on $\overline{\text { CIUUC }}$ test.

Keywords : cohesive soil, dilatancy, triaxial compression test
\end{abstract}

\section{1. はじめに}

堆積年代の新しい沖積軟弱地盤上における建設工事で は, 地盤の支持力不足のためさまざまな問題が生じてい る.この地盤を構成する土要素は正規圧密状態にあり, 上載荷重によりせん断を受けると体積を減少させる方向 にダイレイタンシーが発生する。このとき, 地盤が排水 状態にあれば体積減少を生じるが, 非排水状態の場合, 間隙水圧が発生して土のせん断強度は低下する.

このようにダイレイタンシーは, 土のせん断機構に深 く関係しており, 土の応力〜ひずみ関係や地盤の支持力 を評価するうえで重要な要因となっている. 紫田 ${ }^{11}$ は平 均有効主応力一定の排水試験を行い, ダイレイタンシー 〜軸ひずみ関係が圧密圧力の大きさに無関係に一定の曲 線になることを見出すとともに, Henkel' $ら^{3)}$ の正規圧密粘土の排水三軸圧縮試験結果を用いて, 正規圧密粘土のダイレイタンシー式を提案した。また, 軽部・栗原 ${ }^{4)}$ は圧密非排水三軸試験を行いダイレイタン

* 正会員 工博 基礎地盤コンサルタンツ(株)

（T102 千代田区九段北 1-8-3）

** 工修 日本道路公団広島建設局

( ₹724 東広島市西条町大字西条東 829)

*** 正会員 工修 長野工業高等専門学校講師 土木工学科 ( テ381 長野市大字徳間 716)
シ一特性と強度特性を求め, 粘性土のせん断機構の検討 を行っている.さらに, Shibata and Karube ${ }^{5)}$ は, 中間 主応力を変化させて圧密非排水試験を行い, ダイレイタ ンシーと応力比の関係が中間主応力に影響されないこと を明らかにした。

上記のようなダイレイタンシーに関する研究をもと に, Ohta and $\mathrm{Hata}^{6)}$ は, 塑性体積ひずみを降伏関数と する弾塑性構成式を求めている. また, Mitachi and $\mathrm{Kitago}^{7)}$ は, $K_{0}$ 圧密平面ひずみ試験を行い三軸試験結 果之比較・検討し, 正八面体上でのせん断応力の関係を 調べている. 一方, 清水 ${ }^{81}$ は正規圧密および過圧密粘土 に対して平均有効主応力一定試験を実施し, 応力比とダ イレイタンシーの関係を実験的に定式化するとともに, 降伏関数を考慮し関連流れ則を適用した弾塑性構成式を 提案している.

上記の点に着目し本研究では, 正規圧密状態の飽和粘 性土に対して平均有効主応力一定試験を行い, 体積ひず みおよびせん断ひずみの時間依存性についてその諸特性 を明らかにした。ささらに上記試験結果と圧密非排水三軸 生縮試験結果を比較・検討し，簡便にダイレイタンシー 特性を予測できることを示した。 


\section{2. 試料および実験方法}

\section{(1) 試料}

実験に使用した試料は，新潟県柏崎市米山より採取し た米山土と同県栃尾市から採取した大野土の 2 種類の陸 成粘性土を練り返して再圧密したものである，おのおの の試料の物理的性質を, Table 1 に示す.

練り返した試料の再圧密は, $840 \mu \mathrm{m}$ 以下の粘性土に 水を加えてスラリー状にしたものを内径 $15 \mathrm{~cm}$, 高さ $45 \mathrm{~cm}$ のモールドに入れて行い, 圧密圧は $35 \mathrm{kPa} て ゙$ 圧 密時間は 1 週間とした。脱型した試料から $6.5 \times 6.5 \times$ $15 \mathrm{~cm}$ の直方体を切り出し, ラップで包みパラフィンで シールして 1 週間養生したものを実験に用いた。供試体 は, 直径 $5 \mathrm{~cm}$, 高さ $10 \mathrm{~cm}$ の円柱形のもので, 上述の 1 週間養生した試料からワイヤーソーで切り出して作成 した.

\section{（2）実験方法}

今回行った実験は, 平均有効主応力一定試験 ( $\overline{\text { CIPC }}$ test）と圧密非排水三軸圧縮試験（ $\overline{C I U C}$ test）の 2 種 類である。

a) 平均有効主応力一定試験 ( $\overline{\mathrm{CIPC}}$ test)

この実験は, 平均有効主応力 $\left(p^{\prime}\right)$ を一定に保ちながら, 軸差応力 $(q)$ を段階的に上昇させる三軸試験である。各 載荷段階は, Fig. 1 に示すように, 有効応力経路が C.S.L.に達するまでを 11 分割して決定した．各段階 での軸差応力 $(q)$ と平均有効主応力 $\left(p^{\prime}\right)$ の比の増分 $(\Delta \eta)$ は, $\Delta \eta=M / 11\left(M=q / p^{\prime}\right)$ より求めた.ここで $M$ は,

Table 1 Index Properties of Soil Samples.

\begin{tabular}{l|c|c|c|c|c|c|c}
\hline Soil Sample & Gs & $\begin{array}{l}\omega_{L} \\
(\%)\end{array}$ & $\begin{array}{l}\omega_{p} \\
(\%)\end{array}$ & $\begin{array}{l}1_{p} \\
(\%)\end{array}$ & $\begin{array}{r}\text { Sand } \\
(\%)\end{array}$ & $\begin{array}{r}\text { Si 1 t } \\
(\%)\end{array}$ & $\begin{array}{c}\text { Clay } \\
(\%)\end{array}$ \\
\hline Yoneyama Clay & 2.82 & 64.2 & 36.6 & 27.6 & 42.5 & 29.5 & 28.0 \\
\hline Ohno Clay & 2.67 & 80.2 & 48.7 & 31.5 & 18.0 & 43.9 & 38.1 \\
\hline
\end{tabular}

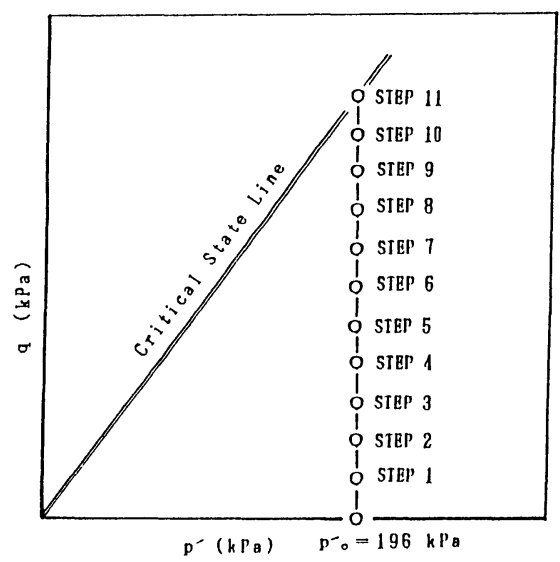

Fig. 1 Effective stress path in $\overline{\mathrm{CIPC}} \mathrm{C}$ test.
米山土および大野土の圧密非排水試験結果 ${ }^{9}$ から決定 し，米山土で $M=1.58$ ，大野土で $M=1.38$ である. ま た，軸圧の増加に対する側圧の減少の比率は $\sigma_{1}^{\prime}: \sigma_{3}^{\prime}=2$ : 1 である. 各載荷段階における載荷時間は 24 時間之 し，排水量および軸変位を測定した。

b) 圧密非排水三軸圧縮試験 ( $\overline{\text { CIUC }}$ test)

圧密圧力 $196 \mathrm{kPa}$ および $392 \mathrm{kPa}$ で等方圧密した後, 非排水せん断を行ったせせん断はひずみ制御で行い，せ ん断速度は $0.07 \% / \mathrm{min}$ であり, 圧密・せん断過程を通 して $98 \mathrm{kPa}$ のバックプレッシャーを加えている.ここ でせん断速度は, 供試体内の間隙水圧の均等化等を考慮 して決定した ${ }^{10) 121}$.

\section{3. 実験結果および考察}

\section{（1）平均有効主応力一定試験結果}

a）体積ひずみ増分およびせん断ひずみ増分の経時変 化

Fig. 2(a)，(b) は，載荷段階 9 における米山土および 大野土の体積ひずみ増分 $\left(d \nu_{d}\right)$ の経時変化を示したもの である.ここで体積ひずみ増分は，次式で定義した。

$$
d \nu_{d}=\Delta V_{i} / V_{i}
$$

ここに, $\Delta V_{i}:$ 各載荷段階における体積変化 $\left(\mathrm{cm}^{3}\right)$

$$
V_{i} \text { : 各載荷段階における初期体積 }\left(\mathrm{cm}^{3}\right)
$$

米山土の場合 (Fig.2(a))，体積ひずみ増分は，載荷 後約 8 分で増加し始め, お上そ 200 分で一定值に収束し ている．これに対して大野土では，体積ひずみ増分が載
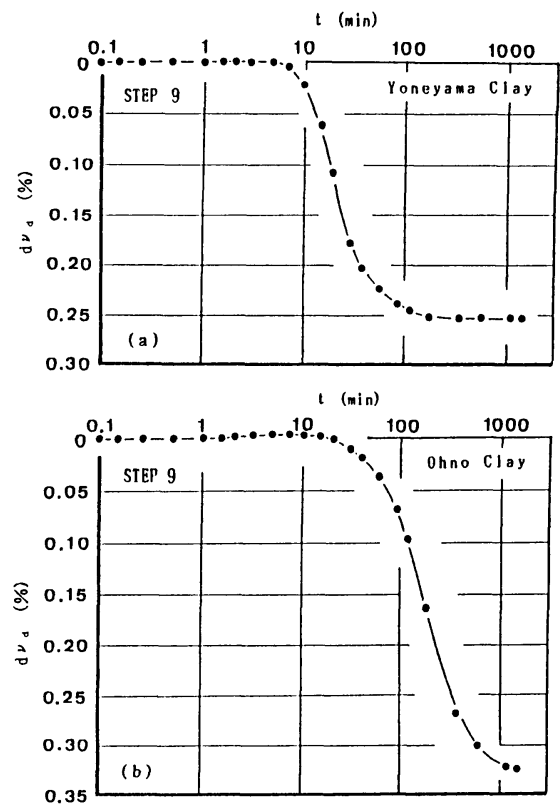

Fig. 2 Typical time-the increment of volumetric strain curve of nine step loading in $\overline{\mathrm{CIPC}} \mathrm{C}$ test. 

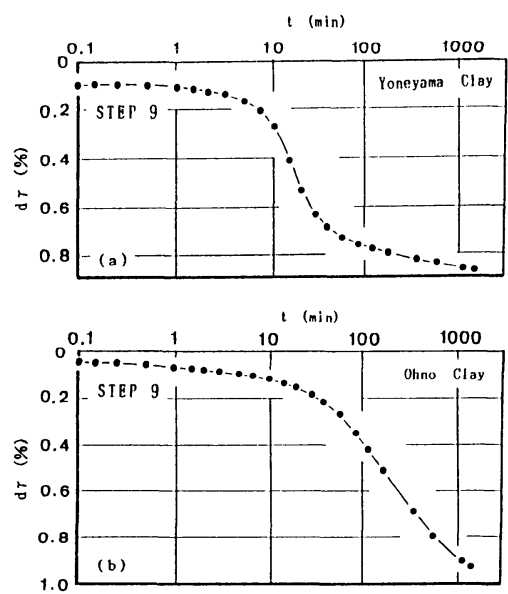

Fig. 3 Typical time - the increment of shear strain curve of nine step loading in $\overline{\mathrm{CIPC}} \mathrm{C}$ test.

荷後約 20 分から増加を始め, 24 時間経過後も一定值に 収束していない(Fig. 2(b)).

次に, 載荷段階 9 のときのせん断ひずみ増分の経時変 化を示すと, Fig. 3 のようになる.ここでせん断ひずみ 増分 $\left(d \gamma^{\prime}\right)$ は, 次式で定義した。

$$
d \gamma=d \varepsilon_{a}-\left(d \nu_{d} / 3\right)
$$

\section{ここに, $d \varepsilon_{a}:$ 軸方向ひずみ増分

$$
d \nu_{d}: \text { 体積ひずみ増分 }
$$

Fig. 3(a)に示すように, 米山土のせん断ひずみ増分は, 載荷直後から即時的に発生し, およそ 10 分で著しい増 加を示す。また，体積ひずみ増分と異なり載荷後 24 時 間経過しても一定値に収束せず，2次変形的傾向を示し ている. 一方，大野土では（Fig. 3(b)) せん断ひずみ 増分が載荷直後から即時的に発生し, 約 60 分経過した 時点から著しい増加傾向を示している. しかし, 米山土 と異なりせん断ひずみ増分は，2次変形的な傾向を示さ ない.

以上のことより，ひずみの時間依存性は，ダイレイタ ンシー（体積ひずみ）よりもせん断変形（せん断ひずみ） に支配されているものと考えられる.

b)ひずみ速度と応力比 $\left(q / p^{\prime}\right)$ の関係

時間に対するひずみの変化の割合を定量的に把握する ために，体積ひずみ速度およびせん断ひずみ速度と応力 比 $\left(q / p^{\prime}\right)$ の関係を調べ, Fig. 4 および Fig. 5 に示した. おのおののひずみ速度は, Walker ${ }^{13)}$ と同様に次式で定 義した。

体積ひずみ速度 $: d \nu_{d} / d(\log t)$

せん断ひずみ速度 : $d \gamma / d(\log t)$ 米山土の体積ひずみ速度は (Fig. 4(a)), 応力比 $\left(q / p^{\prime}\right)$ が 0.75 まで一定であり $\left(d \nu_{d} / d(\log t)=0.03\right), q / p^{\prime}$ が 0.75 以上になると $q / p^{\prime}$ の増加に伴って直線的に増加し
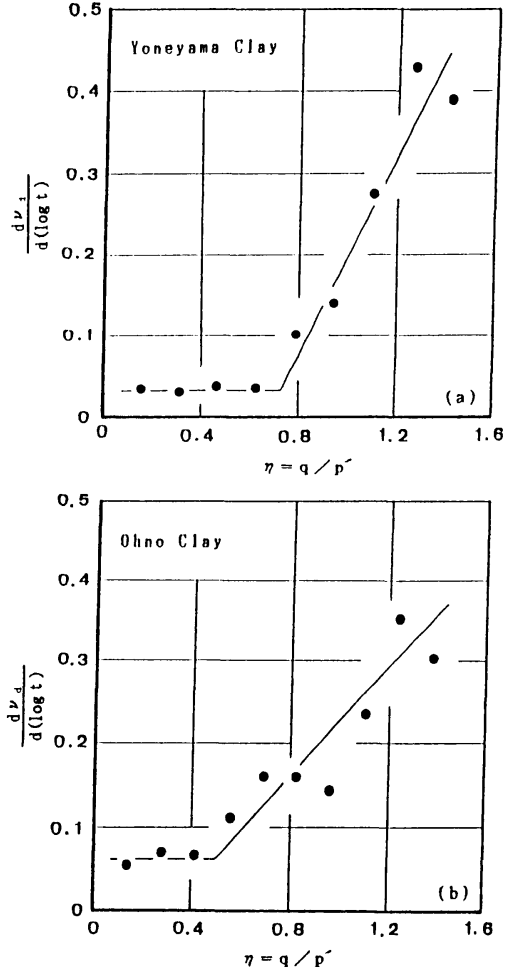

Fig. 4 Relationship between $d \nu_{d} / d(\log t)$ and $\eta$ in $\overline{\mathrm{CIPC} C}$ test.
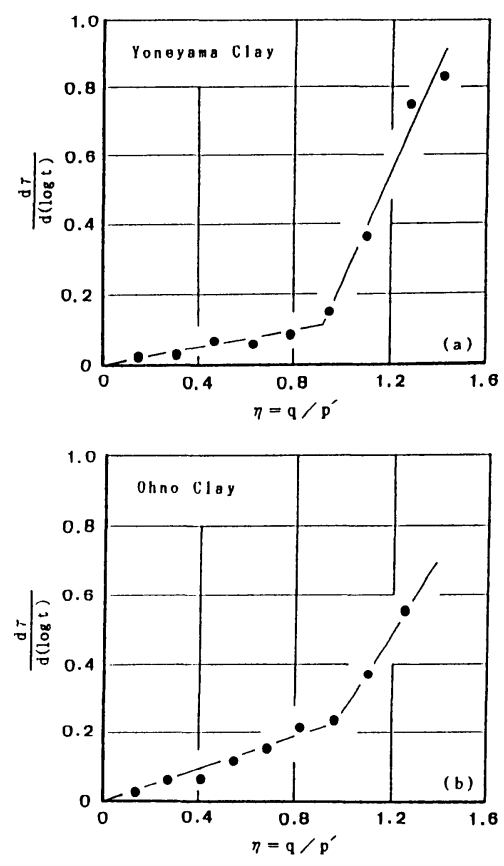

Fig. 5 Relationship between $d \gamma / d(\log t)$ and $\eta$ in $\overline{\text { CIPCC }}$ test. 
ている．また Fig. 4(b) に示すように，大野土の体積ひ ずみ速度は， $q / p^{\prime}$ が 0.5 まで一定值 $\left(d \nu_{d} / d(\log t)=\right.$ 0.06 ）を示し, それ以後 $q / p^{\prime}$ の増加に伴って直線的に 増加している. 特に, 米山土において応力比の増加に伴 う体積ひずみ速度の増加傾向が，顕著であることがわか る.

一方，せん断ひずみ速度は，Fig.5(a)，(b) に示すよ うに, 両試料とも $q / p^{\prime}$ が約 1.0 の点で増加傾向が変化 し， $q / p^{\prime}$ が 1.0 以上になるとせん断ひずみ速度が急激 に増加している．また，大野土と米山土を比較すると， 応力比 $\left(q / p^{\prime}\right)$ が 1.0 以下の範囲では大野土のせん断ひ ずみ速度が米山土のせん断ひずみ速度よりも大きく, $q / p^{\prime}$ が 1.0 以上になると米山土のせん断ひずみ速度が 大きくなっていることがわかる.

c) ダイレイタンシーと軸ひずみの関係

Fig. 6 は, 平均有効主㐫力一定試験から得られたダイ レイタンシー $\left(\nu_{a}\right)$ と軸ひずみ $\left(\varepsilon_{a}\right)$ の関係を示したもので ある．ここでダイレイタンシーと軸ひずみは，各載荷段 階における排水量および沈下量の累積を，圧密終了時の 体積と高さで除して求めた。

図より，大野土および米山土とも軸ひずみが $3 \%$ 以 下の範囲において,ダイレイタンシーと軸ひずみの関係 は直線近似が可能であり，軸ひずみの増加に伴ってダイ レイタンシーが増加する傾向を示している．しかし，軸 ひずみが $4 \%$ を越えると，軸ひずみに対するダイレイ タンシーの増加割合は低下しその直線関係が認められな い.

以上の結果からダイレイタンシーは，軸ひずみが $3 \%$ 以下の領域で軸ひずみの増加に伴って直線的に増加する が, 変形の進行に伴いダイレイタンシーの増分が低下し ていくことがわかる.

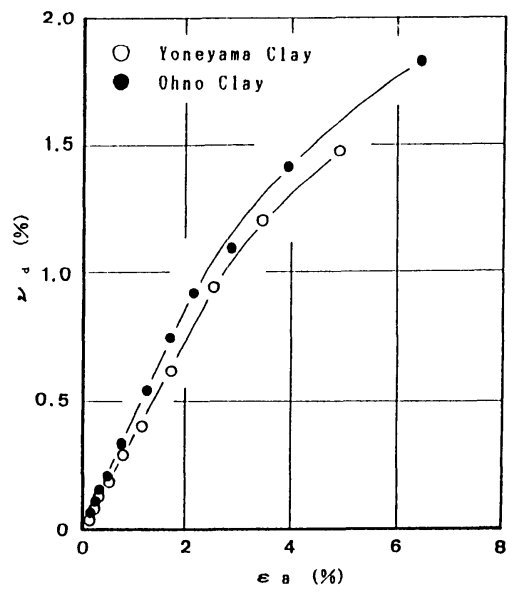

Fig. 6 Relationship between $\nu_{d}$ and axial strain in $\overline{\mathrm{CIPC} C}$ test. d) ダイレイタンシーの増分 $\left(d \nu_{d}\right)$ と応力比 $\left(\tau_{\mathrm{oct}} / \sigma_{m}^{\prime}\right)$ の関係

Fig. 7(a)，(b) は，米山土および大野土の各載荷段階 におけるダイレイタンシーの増分 $\left(d \nu_{d}\right)$ と応力比 $\left(\tau_{\mathrm{oct}}\right)$ $\left.\sigma_{m}^{\prime}\right)$ の関係を示したものである.

図に示すように, 各載荷段階の $d \nu_{d}$ は, $\tau_{\mathrm{oct}} / \sigma_{m}^{\prime}$ の増 加に伴ってほぼ直線的に増加しており, 次式で定式化す ることができる.

$$
d \nu_{d}=D \cdot \frac{\tau_{\mathrm{oct}}}{\sigma_{m}^{\prime}}
$$

\section{ここに, $D$ : 比例定数}

また，ダイレイタンシーは， $d \nu_{d}$ の累積で与えられる ので, 次式から求めることができる.

$$
\begin{aligned}
\nu_{d} & =\sum\left(d \nu_{d}\right)=\Sigma\left(D \cdot \frac{\tau_{\mathrm{oct}}}{\sigma_{m}^{\prime}}\right)=D \cdot \Delta\left(\frac{\tau_{\mathrm{oct}}}{\sigma_{m}^{\prime}}\right) \cdot \frac{n(n+1)}{2} \\
& =\frac{D}{2} \cdot \frac{\tau_{\mathrm{oct}}}{\sigma_{m}^{\prime}} \cdot\left\{\frac{1}{\Delta\left(\frac{\tau_{\mathrm{oct}}}{\sigma_{m}^{\prime}}\right)} \cdot \frac{\tau_{\mathrm{oct}}}{\sigma_{m}^{\prime}}+1\right\}=A\left(\frac{\tau_{\mathrm{oct}}}{\sigma_{m}^{\prime}}\right)^{2}+B \cdot \frac{\tau_{\mathrm{oct}}}{\sigma_{m}^{\prime}}
\end{aligned}
$$

$\Delta\left(\frac{\tau_{\mathrm{oct}}}{\sigma_{m}^{\prime}}\right):$ 応力比の増分

$$
\begin{aligned}
& n \text { ：載荷段階 } \\
& A=\frac{D}{2 \Delta\left(\frac{\tau_{\text {oct }}}{\sigma_{m}^{\prime}}\right)}, \quad B=\frac{D}{2}
\end{aligned}
$$

したがって，大野土および米山土のように砂分，シル
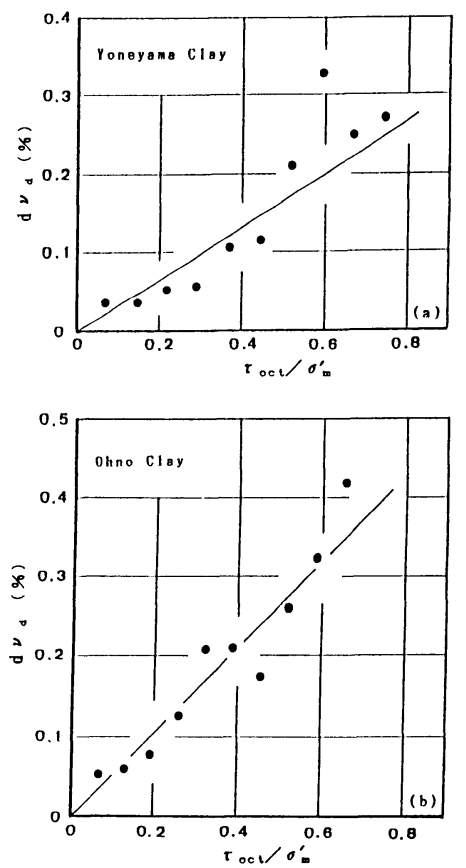

Fig. 7 Relationship between the increment of dilatancy and $\tau_{\text {oct }} / \sigma_{m}^{\prime}$ in $\overline{\text { CIPCC }}$ test. 


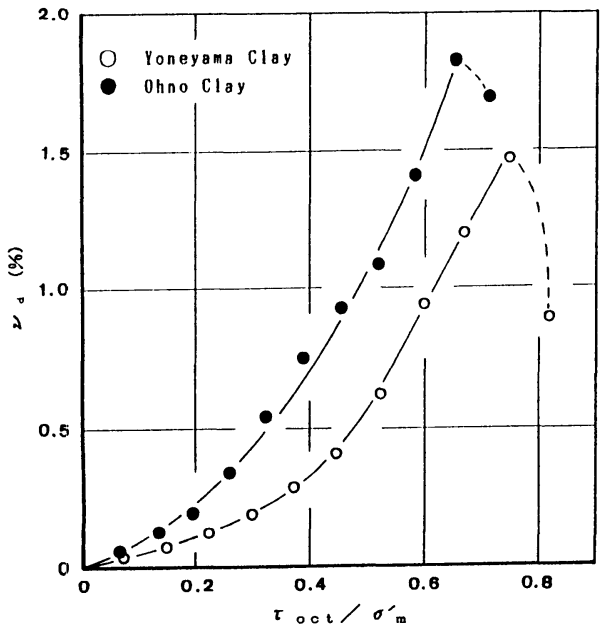

Fig. 8 Relationship between the dilatancy and $\tau_{\text {oct }} / \sigma_{m}^{\prime}$ in $\overline{\text { CIPCC }}$ test.

ト分の多い低塑性粘性土における $\tau_{\mathrm{oct}} / \sigma_{m}^{\prime}$ とダイレイタ ンシー $\left(v_{d}\right)$ の関係は, 紫田 ${ }^{1)}$ が高塑性粘性土について述 ベているような直線的関係ではなく，二次関数形で近似 されることがわかる.

Fig. 8 は,ダイレイタンシー $\left(\nu_{d}\right)$ と $\tau_{\mathrm{oct}} / \sigma_{m}^{\prime}$ の関係を 示したものである. 図よりダイレイタンシーは, $\tau_{\mathrm{oct}} /$ $\sigma_{m}^{\prime}$ の増加に伴って二次曲線的変化を示し, 上述の結果 を裏付けるものであり, 清水 ${ }^{8}$ の行った実験結果とも一 致している.

e）ひずみ増分ベクトル

米山土および大野土のひずみ増分べクトルは, Fig. 9 に示すように，載荷段階が進むに伴ってひずみ増分が増 加し, 有効応力経路が C. S. L. に近づくにつれてベク トルの方向がしだいに鉛直上向きになっていく．本研究 においで, 有効応力経路は載荷段階 11 で C.S. L. に達 し，ひずみ増分べクトルが鉛直上向きになり破壊に至っ ている.

\section{（2）平均有効主応力一定試験結果と非排水三軸圧縮 試験結果の比較}

a) 応力経路

$e-\log p^{\prime}$ 面上の平均有効主応力一定試験と圧密非排 水三軸王縮試験の経路を示すと, Fig. 10(a), (b) のよ うになる。

圧密非排水三軸圧縮試験では, Fig. 10(a) に示すよう に, せん断に伴って平均有効主応力が減少するので, 図 中 $\overline{p^{\prime}}$ の状態は O.C.L. 上にあると考えられる. した がって, $\overline{p^{\prime}}$ の状態に相当するダイレイタンシーは, $\overline{p^{\prime}}$ を通る O. C. L. と平均有効主応力一定試験の経路の交 点における間隙比の差を用いて表わすことができる.ま た，圧密非排水三軸圧縮試験の応力経路は, Fig. 10(b)
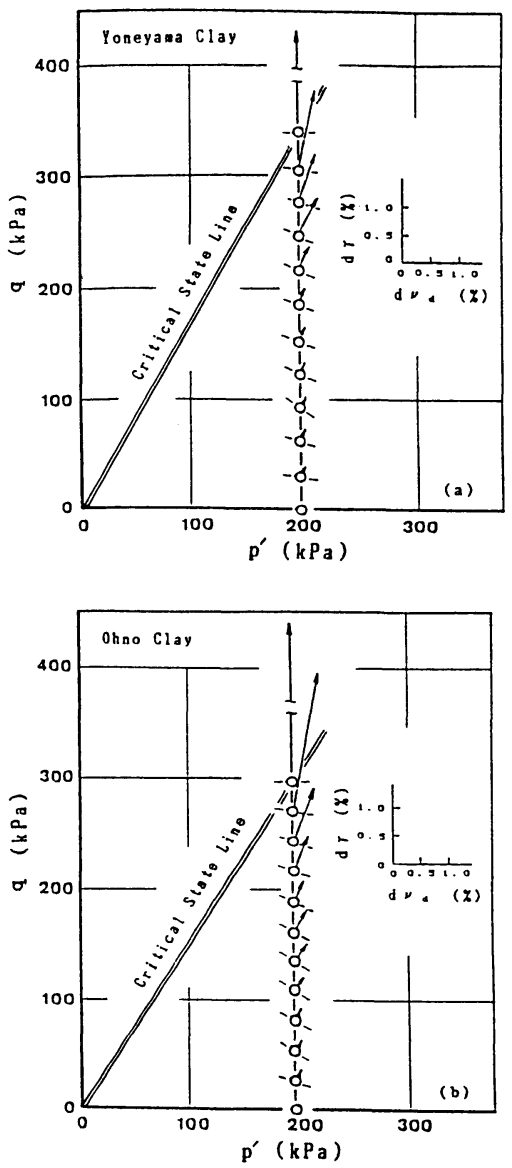

Fig. 9 Change in the increment of strain vector with the number of load steps in $\overline{\mathrm{CIPC}} \mathrm{C}$ test.

に示す A点以下に平均有効主応力が娍少しないので, 図 中S点までしかダイレイタンシーが対応しない．この限 界点 $\mathrm{S}$ を $e^{-} q-p^{\prime}$ の三次元空間上に表わしたものが,

Fig. 11 である. 図より限界点 $\mathrm{S}$ は, $q-p^{\prime}$ 面上において, 圧密非排水三軸圧縮試験の応力経路が C. S. L. に到達 したときの降伏曲線と平均有効主応力一定試験の応力経 路との交点であることがわかる.

b) ダイレイタンシー $\left(\nu_{d}\right)$ と応力比 $\left(\tau_{\mathrm{oct}} / \sigma_{m}^{\prime}\right)$ の関係 平均有効主応力一定試験より得られたダイレイタン シー $\left(\nu_{d}\right)$ および圧密非排水三軸圧縮試験より求めたダイ レイタンシー指数 $(d)$ と $\tau_{\mathrm{oct}} / \sigma_{m}^{\prime}$ の関係を, Fig. 12 に示 す.ここでダイレイタンシー指数は, 圧縮指数 $C_{c}$ およ び膨潤指数 $C_{S}$ を用いて次式より求めた ${ }^{4), 14), 15)}$.

$$
\begin{aligned}
& d=\frac{0.434 C_{c}}{1+e_{0}} \cdot \frac{1}{p_{0}^{\prime}}\left(\Delta u-\Delta \sigma_{m}\right) \\
& d=\frac{0.434 C_{s}}{1+e_{0}} \cdot \frac{1}{p_{0}^{\prime}}\left(\Delta u-\Delta \sigma_{m}\right)
\end{aligned}
$$

図より,ダイレイタンシー指数 $d$ と $\tau_{\mathrm{oct}} / \sigma_{m}^{\prime}$ の関係は, 


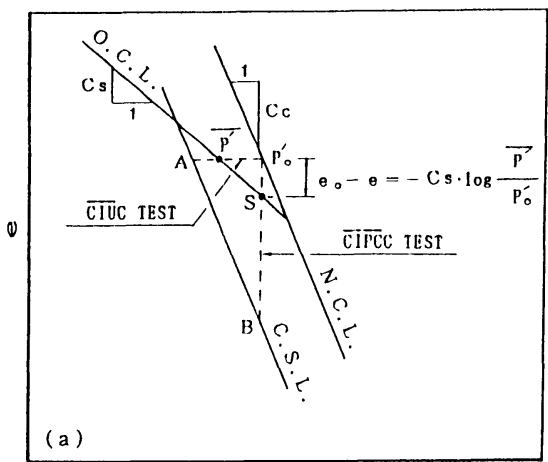

$\log P^{\prime}$

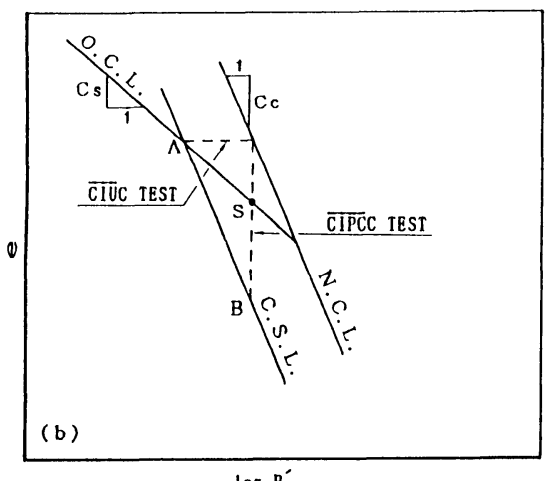

Fig. 10 Key sketch of stress paths in $\overline{\text { CIPCC }}$ test and $\overline{\text { CIUCC }}$ test on $e-\log p^{\prime}$ surface.

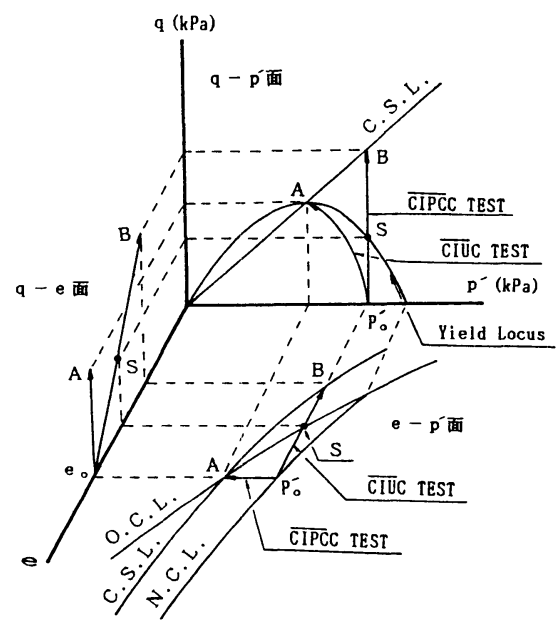

Fig. 11 Key sketch of stress paths in $\overline{\text { CIPC } C}$ test and $\overline{\mathrm{CIU}} \mathrm{C}$ test on $e-q-p^{\prime}$ surface.

圧密圧力の大きさに関係なくほぼ一致した傾向を示して いる.このことより軽部・栗原 ${ }^{4}$ が述べているように， $d-\tau_{\mathrm{oct}} / \sigma_{m}^{\prime}$ の関係が圧密圧力の大きさに影響されないこ とがわかる.
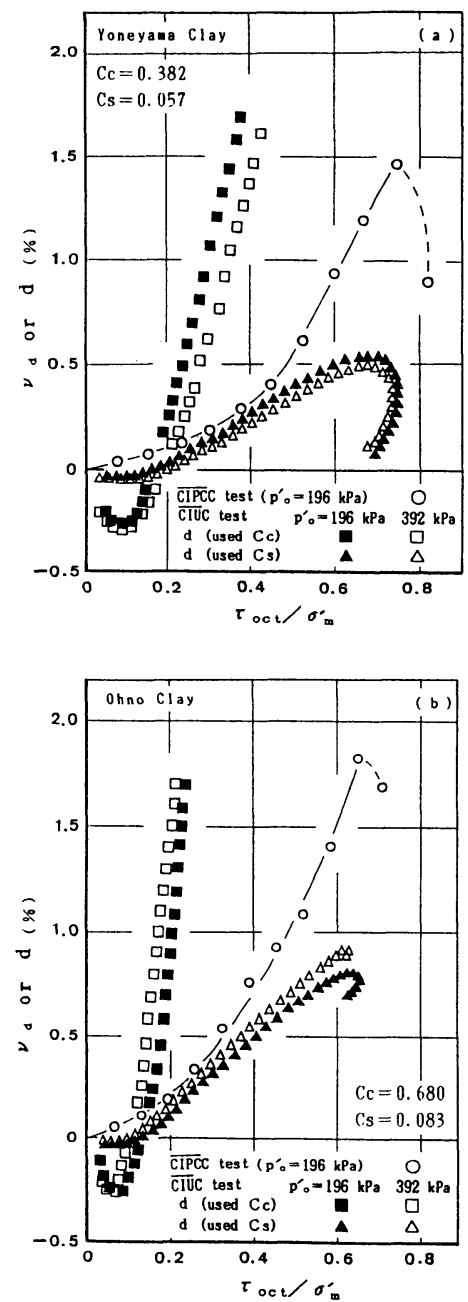

Fig. 12 Relationship between dilatancy $\left(\nu_{d}\right.$ or $\left.d\right)$ and $\tau_{\text {oct }} / \sigma_{m}^{\prime}$.

さらに圧縮指数 $C_{c}$ を用いて算出した $d$ 值は, 膨潤指 数 $C_{s}$ を用いて算出した $d$ 値とかなり異なった挙動を示 している. また， $\tau_{\mathrm{oct}} / \sigma_{m}^{\prime}$ が 0.5 以下の領域において, 膨潤指数 $C_{s}$ を用いて算出した $d$ 値は, 平均有効主応力 一定試験より得られたダイレイタンシー $\left(\nu_{d}\right)$ とほぼ一致 した挙動を示している．このことは, 軽部・原田 ${ }^{14)}$ が述 べているように，圧密非排水三軸圧縮試験の場合，圧密 排水三軸圧縮試験と異なり, 間隙水圧の上昇に伴ってせ ん断中の平均有効主応力が減少するため, ダイレイタン シ一の推定には膨潤指数 $C_{s}$ を用いるのが妥当であるこ とを示している. しかし，先に述べたように， $\tau_{\mathrm{oct}} / \sigma_{m}^{\prime}$ が 0.5 以上になると両者の挙動はかなり異なっている.

c) ダイレイタンシーとせん断応力増分 $\left(\Delta \tau_{\text {oct }} / \sigma_{m 0}^{\prime}\right)$ の関係

Fig. 13(a)，(b) は，平均有効主応力一定試験および 

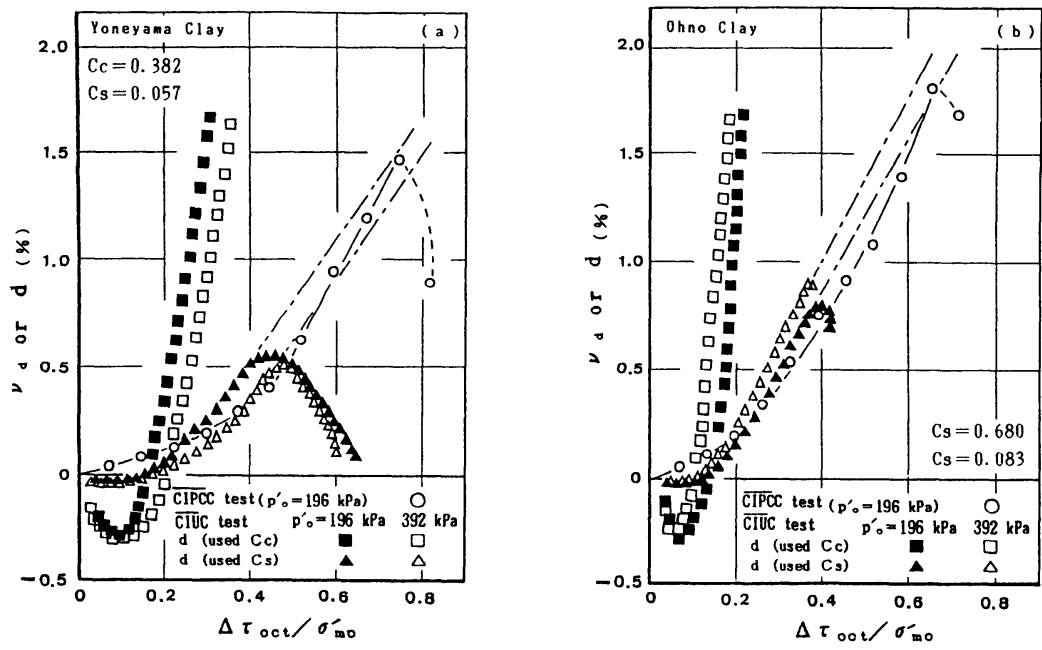

Fig. 13 Relationship between dilatancy $\left(\nu_{d}\right.$ or $\left.d\right)$ and $\Delta \tau_{\text {oct }} / \sigma_{m 0}^{\prime}$.

圧密非排水三軸圧縮試験より求めたせん断応力の増分 $\left(\Delta \tau_{\mathrm{oct}} / \sigma_{m_{0}}^{\prime}\right)$ とダイレイタンシー $\left(\nu_{d}\right.$ or $\left.d\right)$ の関係を示し たものである.ここでせん断応力の増分は，圧密終了時 の平均压密圧力 $\left(\sigma_{m 0}^{\prime}\right)$ で正規化してある.

図より，ダイレイタンシーと $\Delta \tau_{\mathrm{oct}} / \sigma_{m 0}^{\prime}$ の増分の関係 は, 平均圧密圧力 $\left(\sigma_{m 0}^{\prime}\right)$ の大きさに無関係にほぼ一致し た挙動を示すことがわかる．また膨潤指数 $C_{s}$ を用いて 算出した圧密非排水三軸圧縮試験のダイレイタンシー指 数 $d$ は, $d$ 值が最大值に達するまで平均有効主応力一 定試験から得られるダイレイタンシー $\left(\nu_{d}\right)$ とよく一致し ている．一方，圧縮指数 $C_{c}$ を用いて算出した $d$ 值の一 致性は認められない，したがって，圧密非排水三軸圧縮 試験結果より膨潤指数 $C_{s}$ を用いて算出したダイレイタ ンシー指数 $d$ を, $\Delta \tau_{o c t} / \sigma_{m 0}^{\prime}$ に対してプロットしその関 係を単純に延長することによって，平均有効主応力一定 試験におけるダイレイタンシーのおおよその值を推定で きるものと考えられる.

\section{4. 結 論}

本研究は，正規圧密状態の粘性土に対して，排水条件 での平均有効主応力一定試験および圧密非排水三軸圧縮 試験を行い，ダイレイタンシーの時間依存性や試験条件 の違いによる相違点の解明を試みた。ささらに, 圧密非排 水三軸圧縮試験の結果を用いた平均有効主応力一定試験 におけるダイレイタンシーの予測法について検討を行っ た.

本研究によって得られた主要な結果は, 以下のとおり である.

（1）平均有効主応力一定試験において, 各載荷段階 の体積ひずみ増分は一定值に収束するが，せん断ひずみ
増分は徐々に増加し二次変形であるクリープ挙動を示 す.

（2）平均有効主応力一定試験における体積ひずみ速 度およびせん断ひずみ速度は, 応力比 $\left(q / p^{\prime}\right)$ の増加に 伴って直線的に増加し, ある応力比以上になると増加割 合が急增するバイリニア的な挙動を示す.

（３）圧密非排水三軸圧縮試験結果より圧縮指数 $C_{c}$ を用いて算出したダイレイタンシー指数 $(d)$ よりも, 膨 潤指数 $C_{s}$ を用いて算出した $d$ 值の方が, 平均有効主応 力一定試験より求まるダイレイタンシー $\left(\nu_{a}\right)$ と良好な一 致性を示す。

（4）平均有効主応力一定試験より得られるダイレイ タンシー $\left(\nu_{d}\right)$ 挙動は, 圧密非排水三軸圧縮試験より膨潤 指数 $C_{s}$ を用いて算出したダイレイタンシー指数 $(d)$ か らある程度推定が可能である.

謝辞：本研究を行うにあたり，長岡技術科学大学 小川正二教授には有益なご助言とご指導をいただきまし た。ここに感謝いたします。

\section{参 考 文 献}

1）紫田 徹：粘土のダイラタンシーについて, 京都大学防 災研究所年報 6 号, pp. 128 134, 1963.

2) Henkel, D. J. : The Shear Strength of Saturated Remoulded Clays, Research Conference on Shear Strength of Cohesive Soils, ASCE, pp. 533 554, 1960.

3）水野享明・徳光善治・川上 浩: 三軸試験中の間げき水 圧について, 土木学会第 17 回年次学術講演会講演概要集 3, pp. 25 26, 1962.

4）軽部大蔵・栗原則夫：繰り返し粘土のダイレイタンシー とせん断強度について, 土木学会論文報告集, No. 135, 
pp. 16 24, 1966.

5) Shibata, T. and Karube, D. : Influence of the Variation of the Intermediate Principal Stress on the Mechanical Properties of Normally Consolidated Clays, Proc. 6th ICSMFE, Vol. 1, pp. 359 363, 1965.

6) Ohta, H. and Hata, S. : A Theoretical Study of the Stress-Strain Relations for Clays, Soils and Foundations, Vol.11, No. 3, pp. 45 70, 1971.

7) Mitachi, T. and Kitago, S. : The Influence of Stress History and Stress System on the Stress-Strain-Strength Properties of Saturated Clay, Soils and Foundations, Vol. 19, No. 2, pp. 45 61, 1979.

8）清水正善: 正規 - 過圧密粘土の変形特性一応力比〜ひず み増分関係, 第 14 回土質工学研究発表会, pp. 461 464, 1979.

9）高木広道 - 小川正二 - 池田俊雄 - 亀井健史 - 常田 亮 : 低拘束条件での粘性土の強度・変形特性, 第 23 回土質工 学研究発表会, pp. 509 510, 1988.

10) Kimura, T. and Saitoh, K. : The Influence of Strain
Rate on Pore Pressures in Consolidated Undrained Triaxial Tests on Cohesive Soils, Soils and Foundations, Vol.23, No. 1, pp. 80 90, 1983.

11) Nakase, A. and Kamei, T. : Influence of Strain Rate on Undrained Shear Characteristics on $K_{0}$-Consolidated Cohesive Soils, Soils and Foundations, Vol. 26, No. 1, pp. 85 95, 1986.

12）土質工学会編：土質試験法 [第 2 回改訂版], pp. 525, 1979.

13) Walker, L. K. : Secondary Compression in the Shear of Clays, Proc., ASCE, Vol.95, No. SM1, pp. 167 188, 1969.

14）軽部大蔵・原田征四郎：練り返し粘土の平面変形条件に ついて, 土木学会論文報告集, No. 147, pp. 1 9, 1967.

15) Kamei, T. : Dilatancy characteristics of normally consolidated cohesive soils, Soils and Foundations, Vol. 29, No. 1, pp. 165 172, 1989.

(1989.3.27 - 受付) 